\title{
Role of Atorvastatin on Endothelial Cells and Endothelial Progenitor Cells in Cardiovascular Disease
}

\author{
Sampath Kumar ${ }^{1}$, Sujeetha Purushothaman ${ }^{2}$, Papitha Ponnaiya ${ }^{2}$, Keerthi Kishor ${ }^{2}$, Vijaya Anand ${ }^{2 *}$ \\ ${ }^{1}$ Department of Chemistry and Biosciences, SASTRA University, Kumbakonam, Tamil Nadu, India. \\ ${ }^{2}$ Department of Human Genetics and Molecular Biology, Bharathiar University, Coimbatore, Tamil Nadu, India.
}

\begin{tabular}{ll}
\cline { 3 - 3 } ARTICLE INFO & ABSTRACT \\
$\begin{array}{l}\text { Article history: } \\
\text { Received on: } 08 / 01 / 2016\end{array}$ & $\begin{array}{l}\text { The endothelium plays a key role in haemostatic balance. Endothelial progenitor cells (EPCs) are involved in } \\
\text { the maintenance of endothelial haemostasis and in the process of blood vessel formation. Cardiovascular disease }\end{array}$ \\
$\begin{array}{l}\text { Accepted on: } 14 / 04 / 2016 \\
\text { Available online: } 28 / 06 / 2016\end{array}$ & $\begin{array}{l}\text { (CVD) is associated with reduced numbers and dysfunction of endothelial cells (ECs) and EPCs. Inhibition of 3 - } \\
\text { hydroxy-3-methylglutaryl coenzyme A (HMG-Co-A) reductase helps in restoring of EPCs and improvement of } \\
\text { vascular function. This review underlines the pleiotropic effects of atorvastatin on ECs and EPCs. }\end{array}$ \\
$\begin{array}{ll}\text { Key words: } & \\
\text { Endothelial cells; Endothelial } & \end{array}$ \\
$\begin{array}{l}\text { Progenitor cells; } \\
\text { Atherosclerosis; Atorvastatin. }\end{array}$
\end{tabular}

\section{INTRODUCTION}

Cardiovascular disease (CVD) is a most important health problem in the industrialized world for the past few decades (Vijaya Anand et al., 2008). Although there have been many research still people suffer from CVD. Atherosclerosis is a type of CVD and multifactorial disease determined by an inflammatory reaction, which is associated with endothelial dysfunction. It happen when there is impairment in endothelial cells (ECs) and endothelial progenitor cells (EPCs) which may be resulting in cardiovascular outcomes. Statins [3-hydroxy-3-methylglutaryl coenzyme A (HMG-Co-A) reductase inhibitors] therapy is well established effective means of reducing risk of CVD (Vijaya Anand et al., 2009).

\section{ENDOTHELIAL DYSFUNCTION}

Endothelial dysfunction contributes to several disease processes, as occurs in hypertension, hypercholesterolemia,

\footnotetext{
* Corresponding Author
}

Email:avamiet@yahoo.com diabetes and it can likewise result from exposure to environmental agents, such as smoking tobacco products and air pollutants. Endothelial dysfunction is one of the initial manifestations of coronary artery disease, occurring even in the lack of angiographic evidence of disease (Libby, 1995). The primary feature of endothelial dysfunction is the diminished synthesis, release and activity of endothelial derived nitric oxide (NO) and it has been demonstrated to inhibit several components of increasing vasodilators and $\mathrm{NO}$ factors on endothelial function of the atherogenic process. NO acts as an essential role which assists in the proper functioning of endothelial cells. Vascular relaxation can occur by NO derived from endothelium (Ignarro et al., 1987), but if there is impairment in endothelium may affect production of NO, results in decreased proliferation of vascular smooth muscle cells (Garg and Hassid, 1989), and also decreased inhibition of platelet aggregation (Radomski et al., 1992) and endothelialleukocyte interactions with hypercholesterolemia subjects can induce microvascular dysfunction (Gauthier et al., 1995). Inactivation of $\mathrm{NO}$ by superoxide anion $\left(\mathrm{O}_{2} \cdot{ }^{-}\right)$confines the bioavailability of $\mathrm{NO}$ and leads to nitrate tolerance, hypertension and vasoconstriction (Harrison et al., 1997). 


\section{ATORVASTATIN AND ENDOTHELIAL DYSFUNCTION}

Statins could restore endothelial function, relatively, by lowering serum cholesterol levels. Conversely, in a few studies with statins, restoring of endothelial function occurs before significant reduction in serum cholesterol levels (Treasure et al., 1995 and O'Driscoll et al., 1997), which signifying that there are some more beneficial effects such as bioavailability of vasodilators, increase of $\mathrm{NO}$ other than that of cholesterol reduction. Certainly, statins increase endothelial NO formation by stimulating and upregulating endothelial nitric oxide synthase (eNOS) (Kureishi et al., 2000). Statins have been shown to restore the activity of eNOS in the presence of hypoxia, which shows better improvement in restoring of endothelial cells (Laufs et al., 1997) and ox-LDL cholesterol (Laufs et al., 1998). Additionally, statins increase the expression of tissue plasminogen activator antigen (Essig et al., 1998) which helps in breakdown of blood clots and also inhibit the expression of endothelin-1 as it cause vascular remodeling (Hernandez-Perera et al., 1998) thus helps in the production of EPCs.

Increase of blood glucose levels can damage endothelial function. Atorvastatin treatment with metformin for 6 weeks partially prevented the glucose-induced impairment of endothelium-dependent dilation in patients who received treatment (Tousoulis et al., 2010). Atorvastatin therapy was associated with significant reduction in plasma thiobarbituric acid reactive substances and lipid hydroperoxides levels, which was not noted in subjects treated with statins such as pravastatin (Murrow et al., 2012). A study by Zhang et al. (2010) demonstrated the complex mechanism of action of statins explaining their long-term beneficial effects in maintaining the morphological and functional integrity of vascular EC.

Another study demonstrates arterial stiffness and its relation to endothelial dysfunction. There was a reduction in the reflection index with treatment of $\mathrm{N}$-acetylcysteine and atorvastatin signified the improvement of endothelial dysfunction. Further, decrease in high-sensitivity C-reactive protein (hsCRP) and malondialdehyde (MAD) was also observed with the above coupled treatment (Kudaravalli et al., 2011).

Jaumdally et al. (2011) demonstrated that abnormal endothelial, angiogenesis and platelet functions were improved with atorvastatin treatment in diabetic patients. Treatment increased angiopoietin-2 in all groups, angiopoietin-2 increased 3fold in non-diabetic subjects, it increased 2 -fold in diabetic subjects. It has been suggested that other advantages of atorvastatin are to raise the levels of growth factor angiopoietin-2 to normal levels.

The pleiotropic effects of statins are partially mediated through up-regulation of small GTP-binding protein dissociation stimulator (SmgGDS) with a resulting Rac1 degradation and decreased oxidative stress. Atorvastatin helps in the enhanced SmgGDS expression in cultured human umbilical venous EC (HUVEC) and human aortic EC (Minami et al., 2016). Treatment of HUVEC with atorvastatin (1-10 microM) caused a clear increased expression of Tissue transglutaminase (tTgase) in both permeabilised and non-permeabilised HUVEC. By stimulating the expression of tTgase, statins may encourage tTgase-mediated stabilisation of the basement membrane (Soehnlein et al., 2004).

Plasminogen activator inhibitor type-1 (PAI-1) plays a critical role in vascular pathophysiology both at the intra- and extravascular levels. Atorvastatin and fluvastatin favorably modulate the expression of fibrinolytic factors produced by human EC (Izidoro-Toledo et al., 2011). Rosuvastatin and atorvastatin significantly reduced Rho-associated coiled-coil containing protein kinase (ROCK) activity. There was a significant relationship between ROCK activity and flow-mediated dilation for both statins. Short-term therapy of atorvastatin or rosuvastatin inhibits ROCK activity independent of decrease in the levels, cholesterol and also improves endothelial dysfunction in patients with atherosclerosis (Lopez et al., 2000).

Atorvastatin treatment of human umbilical vein EC produced a time-dependent increase in GTP loading of all Rho GTPases and influence the translocation of small Rho GTPases from the cell membrane into the cytoplasm. Atorvastatin significantly attenuates thrombin-induced human umbilical vein EC permeability, elevated VE-cadherin targeting to cell junctions and preserves junction integrity. Atorvastatin treatment also increases the activator protein-1 DNA binding mediated at the level of small GTP and also inhibits isoprenylation of Ras or Rho, accompanied by decreased in the inflammatory response. It also preserves the integrity of the cellular junction (Dichtl et al., 2003).

\section{ENDOTHELIAL PROGENITOR CELLS}

EPCs are hematopoietic stem cells, which are precursor cells that express some cell surface markers characteristic of mature endothelium (Liu et al., 2011). Vascular endothelium plays an essential role in maintaining and regulating vascular tone, structure, growth, fibrinolysis, and homeostasis, thus protecting the vessels from inflammation, immune response, thrombosis and CVD. Thus, alterations in EPCs may result in CVDs (Xiao et al., 2013)

\section{ATORVASTATIN AND ENDOTHELIAL PROGENITOR CELLS}

EPCs are a subtype of hematopoietic stem cells, which contribute to the restore of injured endothelium. EPCs enhance ischemia-induced revascularization (Fuyong Du et al., 2012), accelerate re-endothelialization following carotid balloon injury (Wan et al., 2010; Murohara et al., 2000) and enhance postischemic cardiac function (Walter et al., 2002). Landmesser $e t$ al. (2004) finding reveals that increased eNO availability is necessary for statin-induced enhancement of endothelial progenitor cell mobilization, neovascularization, left ventricular dysfunction, myocardial neovascularization and survival after myocardial infarction (MI). Bioavailability of eNO after MI possibly represents a significant therapeutic target in heart failure patients after MI and mediates positive effects of statin therapy 
after MI. In patients with stable coronary heart disease (CHD), administration of statins for four weeks improved the number of circulating EPCs and enhanced functional capacity in stable CHD patients (Kawamoto et al., 2001). Minami et al. (2009) study demonstrated that lipid lowering therapy with atorvastatin increased EPC numbers and decreased microRNA-221/222 levels in CHD patients. Atorvastatin pretreatment significantly increased the amount of EPCs after cardiopulmonary bypass surgery, by a mechanism independent of plasma levels of cytokines and cholesterol (Vasa et al., 2001).

Atorvastatin, also inhibited homocysteine-induced dysfunction and apoptosis in EPCs, which may be related to its effects on suppressing oxidative stress through up-regulation of Akt/eNOS and down-regulation of p38MAPK/caspase-3 signaling pathway (Minami et al., 2009). Atorvastatin also promoted homocysteine-induced activation of NADPH oxidase as well as the over expression of Nox4 mRNA and p-p38MAPK protein indicating, possibly favorable effects on EPCs function (Spadaccio et al., 2010). Atorvastatin improved proliferation of EPCs (Bao et al., 2010). Consumption of $40 \mathrm{mg}$ dose of atorvastatin could also decrease the levels of circulating endothelial-derived microparticles and increase the number of circulating EPCs in ischemic cardiomyopathy patients when compared to a $10 \mathrm{mg}$ dose of atorvastatin. This effect may be independent of the decrease of lipids, oxLDL and hsCRP (Hibbert et al., 2011). EPCs migrate from the bone marrow into the peripheral circulation to sites of injured endothelium and are involved in endothelial repair and vascular regeneration (Huang et al., 2012). During these processes, EPCs are exposed to oxidative stress condition, a crucial pathological condition, which occurs during vascular injury and limits the efficacy of EPCs in the repair of injured endothelium (Li et al., 2015).

\section{CONCLUSION}

Atorvastatin enhances the restoring of endothelial cells, which helps in improved vascularisation in patients with CVD. It augments the production of endothelial progenitor cells, thus helps in restoring endothelial cells for prevention of CVD. Atorvastatin may play a beneficial role in endothelial function and better clinical outcomes in patients undergoing coronary interventions.

\section{REFERENCES}

Bao XM, Wu CF, Lu GP. Atorvastatin inhibits homocysteineinduced oxidative stress and apoptosis in endothelial progenitor cells involving Nox4 and p38MAPK. Atherosclerosis. 2010;210(1):114-21.

Dichtl W, Dulak J, Frick M, Alber HF, Schwarzacher SP, Ares MP, Nilsson J, Pachinger O, Weidinger F. HMG-CoA reductase inhibitors regulate inflammatory transcription factors in human endothelial and vascular smooth muscle cells. Arterioscler Thromb Vasc Biol. 2003;23(1):58-63.

Essig M, Nguyen G, Prie D, Escoubet B, Sraer JD, Friedlander G. 3-Hydroxy-3-methylglutaryl coenzyme A reductase inhibitors increase fibrinolytic activity in rat aortic endothelial cells. Role of geranylgeranylation and Rho proteins. Circ. Res. 1998;83:683-90.
Fuyong Du,Jun Zhou, Ren Gong, Xiao Huang, Meghana Pansuria, Anthony Virtue, Xinyuan Li, Hong Wang, Xiao-Feng Yang. Endothelial progenitor cells in atherosclerosis. Front Biosci. 2012;17:2327-2349.

Garg UC, Hassid A. Nitric oxide generating vasodilators and 8bromocyclic guanosine monophosphate inhibit mitogenesis and proliferation of cultured rat vascular smooth muscle cells. J. Clin. Invest. 1989;83:1774-77.

Gauthier TW, Scalia R, Murohara T, Guo JP, Lefer AM. Nitric oxide protects against leukocyte-endothelium interactions in the early stages of hypercholesterolemia. Arterioscler. Thromb. Vasc. Biol. 1995; 15:1652-59.

Harrison DG. Cellular and molecular mechanisms of endothelial cell dysfunction. J. Clin. Invest. 1997;100:2153-57.

Hernandez-Perera O, Perez-Sala D, Navarro-Antolin J, Sanchez-Pascuala R, Hernandez G, Diaz C, Lamas S. Effects of the 3hydroxy-3-methylglutaryl-CoA reductase inhibitors, atorvastatin and simvastatin, on the expression of endothelin -1 and endothelial nitric oxide synthase in vascular endothelial cells. J. Clin. Invest. 1998;101:2711-19.

Hibbert B, Ma X, Pourdjabbar A, Simard T, Rayner K, Sun J, Chen YX, Filion L, O'Brien ER. Pre-procedural atorvastatin mobilizes endothelial progenitor cells:clues to the salutary effects of statins on healing of stented human arteries. PLoS One. 2011;6(1):e16413.

Huang B, Cheng Y, Xie Q, Lin G, Wu Y, Feng Y, Gao J, Xu D. Effect of $40 \mathrm{mg}$ versus $10 \mathrm{mg}$ of atorvastatin on oxidized low-density lipoprotein, high-sensitivity C-reactive protein, circulating endothelialderived microparticles, and endothelial progenitor cells in patients with ischemic cardiomyopathy. Clin Cardiol. 2012;35(2):125-30.

Ignarro LJ, Buga GM, Wood KS, Byrns RE, Chaudhuri G. Endotheliumderived relaxing factor produced and released from artery and vein is nitric oxide. Proc. Natl. Acad. Sci. 1987;84:9265-69.

Izidoro-Toledo TC, Guimaraes DA, Belo VA, Garlic RF, Tanus-Santos JE. Effects of statins on matrix metalloproteinases and their endogenous inhibitors in human endothelial cells. Naunyn Schmiedebergs Arch Pharmacol. 2011;383(6):547-54.

Jaumdally RJ, Lip GY, Varma C, Blann AD. Impact of highdose atorvastatin on endothelial, platelet, and angiogenic indices:effect of ethnicity, cardiovascular disease, and diabetes. Angiology. 2011; 62(7):571-8.

Kawamoto A, Gwon HC, Iwaguro H, Yamaguchi JI, Uchida S, Masuda H, Silver M, Ma H, Kearney M, Isner JM, Asahara T. Therapeutic potential of ex vivo expanded endothelial progenitor cells for myocardial ischemia. Circulation. 2001;103:634-37.

Kudaravalli J. Improvement in endothelial dysfunction in patients with systemic lupus erythematosus with $\mathrm{N}$-acetylcysteine and atorvastatin. Indian J Pharmacol. 2011;43(3):311-5.

Kureishi Y, Luo Z, Shiojima I, Bialik A, Fulton D, Lefer DJ, Sessa WC, Walsh K. The HMG-CoA reductase inhibitor simvastatin activates the protein kinase Akt and promotes angiogenesis in normocholesterolemic animals. Nat. Med. 2000;6:1004-10.

Landmesser U, Engberding N, Bahlmann FH, Schaefer A, Wiencke A, Heineke A, Spiekermann S, Hilfiker-Kleiner D, Templin C, Kotlarz D, Mueller M, Fuchs M, Hornig B, Haller H, Drexler H. Statininduced improvement of endothelial progenitor cell mobilization, myocardial neovascularization, left ventricular function, and survival after experimental myocardial infarction requires endothelial nitric oxide synthase. Circulation. 2004;110(14):1933-9.

Laufs U, Fata VL, Liao JK. Inhibition of 3-hydroxy-3methylglutaryl (HMG)-CoA reductase blocks hypoxiamediated downregulation of endothelial nitric oxide synthase. J. Biol. Chem. 1997;272:31725-29.

Laufs U, La Fata V, Plutzky J, Liao JK. Upregulation of endothelial nitric oxide synthase by HMG CoA reductase inhibitors. Circulation 1998;97:1129-35.

Li DW, Li JH, Wang YD, Li GR. Atorvastatin protects endothelial colony-forming cells against $\mathrm{H} 2 \mathrm{O} 2$-induced oxidative damage by regulating the expression of annexin A2. Mol Med Rep. 2015;12(6):7941-8. 
Libby P. Molecular bases of the acute coronary syndromes. Circulation. 1995;91:2844-50.

Liu B, Cao HM, Li GY, Liu M, Feng J, Li J, Wang Q. Effects of rosuvastatin versus atorvastatin on rho-associated coiled-coil containing protein kinase activity and endothelial function in patients with atherosclerosis. J Int Med Res. 2011; 39(6):2314-22.

Lopez S, Peiretti F, Bonardo B, Juhan-Vague I, Nalbone G. Effect of atorvastatin and fluvastatin on the expression of plasminogen activator inhibitor type-1 in cultured human endothelial cells Atherosclerosis. 2000;52(2):359-66.

Minami T, Satoh K, Nogi M, Kudo S, Miyata S, Tanaka S, Shimokawa H. Statins up-regulate SmgGDS through $\beta 1$-integrin/Akt1 pathway in endothelial cells. Cardiovasc Res. 2016;109(1):151-61.

Minami Y, Satoh M, Maesawa C, Takahashi Y, Tabuchi T, Itoh T, Nakamura M. Effect of atorvastatin on microRNA 221 / 222 expression in EPCs obtained from patients with coronary artery disease. Eur J Clin Invest. 2009;39(5):359-67.

Murohara T, Ikeda H, Duan J, Shintani S, Sasaki K, Eguchi H, Onitsuka I, Matsui K, Imaizumi T. Transplanted cord blood-derived endothelial precursor cells augment postnatal neovascularization. J. Clin. Invest. 2000;105:1527-36.

Murrow JR, Sher S, Ali S, Uphoff I, Patel R, Porkert M, Le NA, Jones D, Quyyumi AA. The differential effect of statins on oxidative stress and endothelial function:atorvastatin versus pravastatin. J Clin Lipidol. 2012;6(1):42-9.

O'Driscoll G, Green D, Taylor RR. Simvastatin, an HMGcoenzyme A reductase inhibitor, improves endothelial function within 1 month. Circulation. 1997;95:1126-31.

Radomski MW, Rees DD, Dutra A, Moncada S. S-Nitroso-glutathione inhibits platelet activation in vitro and in vivo. Br. J. Pharmacol. 1992;107:745-49.

Soehnlein O, Eskafi S, Schmeisser A, Kloos H, Daniel WG, Garlichs CD. Atorvastatin induces tissue transglutaminase in human endothelial cells. Biochem Biophys Res Commun. 2004;322(1):105-9.

Spadaccio C, Pollari F, Casacalenda A, Alfano G, Genovese J, Covino E, Chello M. Atorvastatin increases the number of endothelial progenitor cells after cardiac surgery:a randomized control study. J Cardiovasc Pharmacol. 2010;55(1):30-8.

Tousoulis D, Koniari K, Antoniades C, Miliou A, Noutsou M, Nikolopoulou A, Papageorgiou N, Marinou K, Stefanadi E, Stefanadis C. Impact of 6 weeks of treatment with low-dose metformin and atorvastatin on glucose-induced changes of endothelial function in adults with newly diagnosed type 2 diabetes mellitus:A single-blind study. Clin Ther. 2010;32(10):1720-8.

Treasure CB, Klein JL, Weintraub WS, Talley JD, Stillabower ME, Kosinski AS, Zhang J, Boccuzzi SJ, Cedarholm JC, Alexander RW.
Beneficial effects of cholesterol-lowering therapy on the coronary endothelium in patients with coronary artery disease. New Engl. J. Med. 1995;332:481-87.

Vasa M, Fichtlscherer S, Adler K, Aicher A, Martin H, Zeiher AM, Dimmeler S. Increase in circulating endothelial progenitor cells by statin therapy in patients with stable coronary artery disease. Circulation. 2001;103:2885-90.

Vijaya Anand A, Chenniappan M, Kalavathy S, Uma K , Saravanan MP, Sampath Kumar P. Redeeming measures of atorvastatin in the risk factors of cardiovascular diseases. International journal of Pharmacology. 2008;4(4)305-309.

Vijaya Anand A, Chandrasekharan M, Kalavathy S, Uma K, Saravanan MP, Mohamed Saleem Gani A, Vijaya Kumar K, Senthil R, Sampath Kumar P. The influencing aspects of atorvastatin on C-reactive protein and Lipid profile in patients with stroke. International journal of Biological Chemistry.2009;3(1):30-34.

Walter DH, Rittig K, Bahlmann FH, Kirchmair R, Silver M, Murayama T, Nishimura H, Losordo, DW, Asahara T, Isner JM. Statin therapy accelerates reendothelialization:a novel effect involving mobilization and incorporation of bone marrow-derived endothelial progenitor cells. Circulation. 2002;105:3017-24.

Wan J, Lu LJ, Miao R, Liu J, Xu XX, Yang T, Hu QH, Wang J. Alterations of bone marrow derived endothelial progenitor cells following acute pulmonary embolism in mice. Exp boil med. 2010;235(8):989-98.

Werner N, Priller J, Laufs U, Endres M, Bohm M, Dirnagl U, Nickenig G. Bone marrow derived progenitor cells modulate vascular reendothelialization and neointimal formation: effect of 3-hydroxy-3methylglutaryl coenzyme a reductase inhibition. Arterioscler. Thromb. Vasc. Biol. 2002;22:1567-72.

Xiao H, Qin X, Ping D, Zuo K. Inhibition of Rho and Rac geranylgeranylation by atorvastatin is critical for preservation of endothelial junction integrity. PLoS One. 2013;8(3):e59233.

Zhang XS, Ren JH, Lu JP, Fan Y. Atorvastatin protects against angiotensin II-induced injury and dysfunction in human umbilical vein endothelial cells through bradykinin 2 receptors. J Car. Pharmacol. 2010;56(2):171-6.

\section{How to cite this article:}

Sampath Kumar, Sujeetha Purushothaman, Papitha Ponnaiya, Keerthi Kishor, Vijaya Anand. Role of Atorvastatin on Endothelial Cells and Endothelial Progenitor Cells in Cardiovascular Disease. J App Pharm Sci, 2016; 6 (06): 151-154. 